\title{
A Tripeptidyl Ensemble Perspective of Interactive Control of Growth Hormone Secretion
}

\author{
Johannes D. Veldhuis \\ Mayo Medical and Graduate School of Medicine, Mayo Clinic, Rochester, Minn., USA
}

\section{Key Words}

Growth hormone · Growth hormone-releasing hormone $\cdot$ Growth hormone-releasing peptide $\cdot$ Ghrelin . Somatostatin - Insulin-like growth factor I - Threefold peptide control pathway - Sex-steroid hormones . Gender · Oestrogen · Oestradiol · Women

\begin{abstract}
Current investigational tools in molecular biology, biochemistry and integrative physiology have revealed an increasing array of signals that influence growth hormone $(\mathrm{GH})$ secretion. The present perspective combines these factors under a simplified final-common pathway model of threefold joint control by GH-releasing hormone, GH-releasing peptide/ghrelin and somatostatin. This concept is highlighted from the viewpoint of sex steroid- and age-dependent modulation of the peptide trilogy listed above.
\end{abstract}

Copyright ( $\odot 2003$ S. Karger AG, Basel

\section{Overview of Growth Hormone Neuroregulation}

Principal anatomical components of the somatotropic axis comprise the hypothalamic regulatory centres, the anterior pituitary gland and the peripheral target organs. Targets of growth hormone $(\mathrm{GH})$ action include the liver, kidney, skeleton, brain, breast, ovary, testis, heart, skele- tal muscle, gastrointestinal tract, spleen, thymus, bone marrow and skin. GH stimulates the cell-specific biosynthesis of insulin-like growth factor I (IGF-I), which in turn mediates many, but not all, growth effects. In certain cells, such as prechondrocytes and mature adipocytes, $\mathrm{GH}$ acts independently of local IGF-I production or reception. Organotropic hormones also drive in situ IGF-I gene expression and regulate IGF-receptor and -binding protein activities. Homeostasis proceeds by multivalent signalling from GH, IGF-I and an ensemble of regulatory peptides, and is discussed below. Adaptive control requires repeated gradual adjustments in feedforward and feedback drive. The sensitivity and efficacy of the feedback drive implies that the dose-response interactions are modulated by homologous and heterologous effectors, sex steroids, cortisol, thyroxine, systemic metabolites and intrapituitary factors [1-4].

The majority of somatotropic signals converge on a final-common trilogy of regulatory peptides (fig. 1). In this model, GH-releasing hormone (GHRH) and somatostatin exert opposing (i.e. stimulatory and inhibitory) actions on somatotrope cells and achieve (paradoxical) synergy when presented in appropriately timed succession [5-8]. Ghrelin, a potent acylated peptide synthesized in the stomach and anterior pituitary gland, drives $\mathrm{GH}$ secretion via a novel cascade of hypothalamo-hypophysial mechanisms [9-12]. All three peptidyl effectors and cognate signalling pathways are regulated by a reversible autofeedback enforced by GH and IGF-I (fig. 1a) and spe-

\begin{tabular}{|c|c|}
\hline KARGER & $\begin{array}{l}\text { (c) } 2003 \text { S. Karger AG, Basel } \\
0301-0163 / 03 / 0607-0086 \$ 19.50 / 0\end{array}$ \\
\hline $\begin{array}{l}\text { Fax + } 41613061234 \\
\text { E-Mail karger@karger.ch } \\
\text { www.karger.com }\end{array}$ & $\begin{array}{l}\text { Accessible online at: } \\
\text { www.karger.com } / \mathrm{hre}\end{array}$ \\
\hline
\end{tabular}

Prof. J.D. Veldhuis, Division of Endocrinology and Metabolism Department of Internal Medicine, General Clinical Research Center Mayo Medical and Graduate School of Medicine, Mayo Clinic 200 First Street SW, Rochester, MN 55905 (USA)

Tel. +1 507255 0906, Fax +1 507255 0901, E-Mail veldhuis.johannes@mayo.edu 
cific actions of oestradiol (fig. 1b) [1]. The physiological importance of oligopeptide control is illustrated by the ability of the combined infusion of $L$-arginine (a presumptive repressor of somatostatinergic outflow) and GHRH or GH-releasing peptide (GHRP) to elicit nearmaximal GH secretion throughout the human lifetime [13-18]. In contrast, single administrations of GHRH, GHRP or $L$-arginine cause variable release of GH depending on age, sex, body composition and nutrient status.

\section{GH-Releasing Hormone: A Prime Secretagogue}

The core component of the dynamics of GH uses an essential feedforward stimulation by GHRH $[1-3,8,13$, 14, 19-25]. Direct monitoring of the pulsed release of GHRH into hypothalamo-pituitary portal blood has established strong (50-70\%) temporal concordance of GHRH and GH peaks in four mammalian species [2628]. The secretagogic role of GHRH has been observed in studies of GH secretion in rare genetic diseases and interventional experiments conducted both in vitro and in vivo. For example, the mean concentrations of $\mathrm{GH}$ and the GH pulse amplitude are reduced significantly by: (1) passive immunoneutralization of GHRH; (2) pharmacological blockade of the GHRH receptor; (3) chemical or electrolytic lesioning of GHRH neurons in the arcuate nucleus; and (4) loss-of-function mutations of the GHRH receptor in humans (initially described in the so-called 'dwarfs of Sindh') and mice (lit/lit dwarf) (fig. 2a) [1, 6, $14,20,29]$.

The GHRH receptor-effector pathway has the unique and multifold capability to: (1) rapidly stimulate the exocytotic release of GH-containing secretory granules; (2) subacutely induce transcriptionally dependent de novo GH biosynthesis; (3) promote chronic somatotrope cell hypertrophy, hyperplasia and tumour formation; (4) upregulate (in the immature rat) and down-regulate (in the adult animal) the cognate pituitary receptor; (5) increase expression of pituitary ghrelin peptide and receptor; (6) synergize with GHRP-receptor agonists in vivo (fig. 2b); (7) promote somatostatin secretion in vivo and in vitro; (8) induce marked (rebound-like) GH secretion by somatostatin-primed somatotropes [5, 19, 20, 30-35].

No current network-like algebraic formalism embodies this unique collection of regulatory properties. Non-aromatizable androgens up-regulate the production and reception of GHRH in the rodent through indirect mechanisms, as the androgen receptor is not detectable in

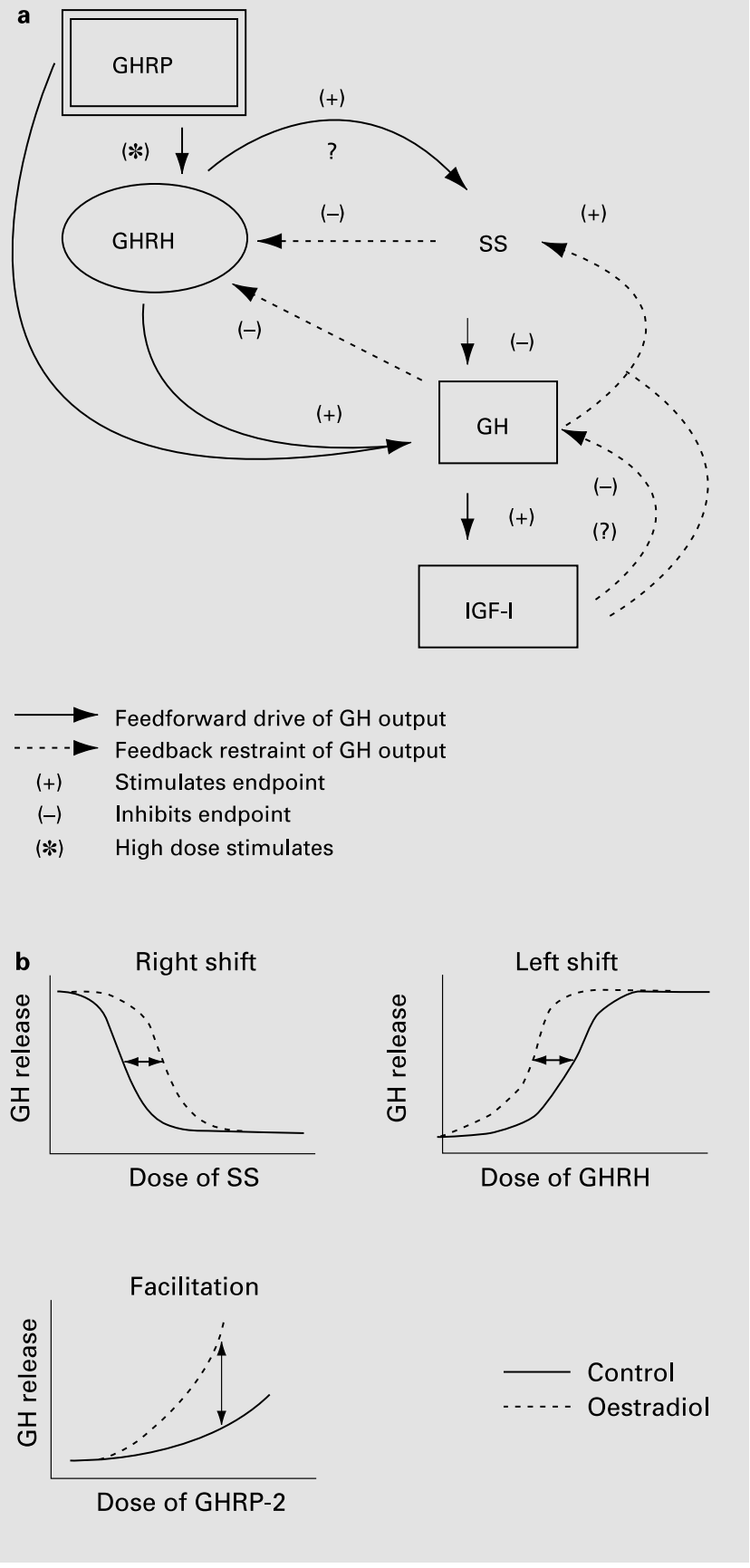

Fig. 1. a Concept of ensemble control of GH secretion by GHRH, GHRP/ghrelin, somatostatin (SS), GH and IGF-I. b Sites and mechanisms of action of oestradiol on feedback by SS (top left) and feedforward by GHRH and GHRP-2 (top right and bottom left) discerned by infusion of a single effector in post-menopausal women. 
Fig. 2. a Profound ( $>30$-fold) attenuation of GH secretory burst mass in two young-adult siblings with a homozygous truncational mutation of the GHRH receptor. The generation of recurrent $\mathrm{GH}$ pulses $\left(\mathrm{p}<10^{-6}\right)$ and unfolding of 24-hour rhythmicity $\left(\mathrm{p}<10^{-3}\right)$, however, are clearly retained. Serum concentrations of GH were measured by high-sensitivity immunofluorometric assay of blood samples collected every $10 \mathrm{~min}$ for $24 \mathrm{~h}$. In both patients, bolus injection of GHRP-2 stimulated release of $\mathrm{GH}$ by several fold. The normal daily GH pulse frequency shows that factors other than GHRH receptordependent signalling direct the timing properties of pulse renewal. Similarly, the nycthemeral rhythmicity of GH release is independent of GHRH signalling in timing, but not in absolute amplitude. Approximate entropy (ApEn) estimates are elevated by $>5$ standard deviations (SD) above age- and sexmatched control values. The latter anomaly indicates profound erosion of normal subpattern reproducibility otherwise maintained via repeated incremental feedforward adjustments that include GHRH. Adapted, with permission, from Roelfsema et al. [29]: ${ }^{\circ}$ The Endocrine Society. b Marked (120fold) feedforward drive by combined intravenous infusion of GHRH and GHRP-2 or saline (placebo) continuously over $24 \mathrm{~h}$ in a post-menopausal woman.
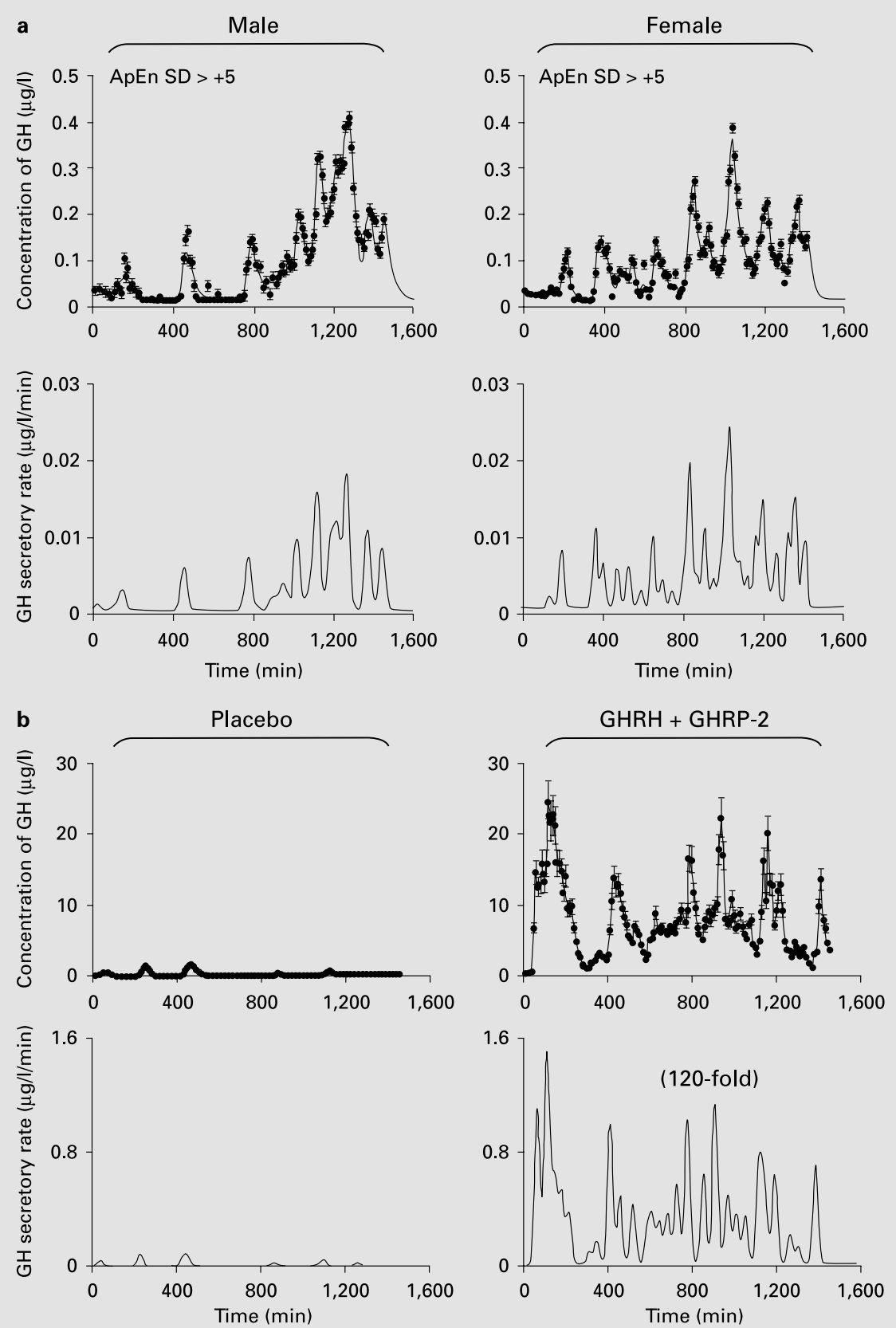

GHRH neurons. The oestrogen receptor (OR) subtype alpha is expressed in two-thirds of the arcuate-nucleus GHRH neurons in both men and women. Oestrogen agonists down-regulate hypothalamic synthesis and pituitary reception of the GHRH stimulus in the adult rat; and, conversely, transgenic silencing of OR- $\alpha$ expression de- pletes IGF-I in the female mouse [1]. In contrast, human studies show that oestradiol up-regulates pituitary sensitivity to GHRH, when monitored under putative somatostatin withdrawal caused by pre-treatment with $L$ arginine. In theory, the last mechanism could contribute to elevated GH secretory-burst mass in puberty (fig. 3). 

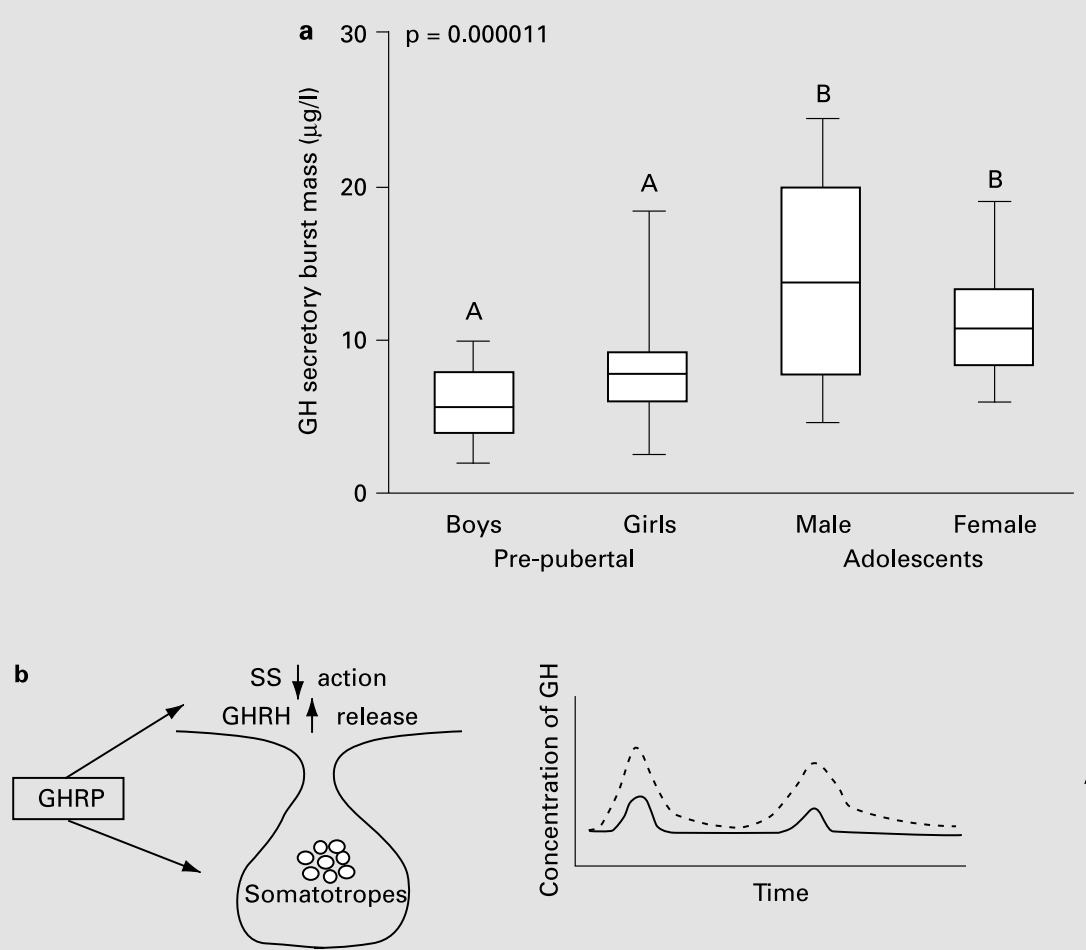

Secretory

burst mass

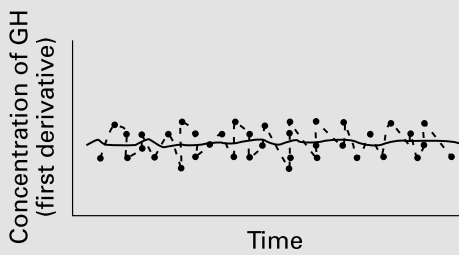

4 Pattern

irregularity
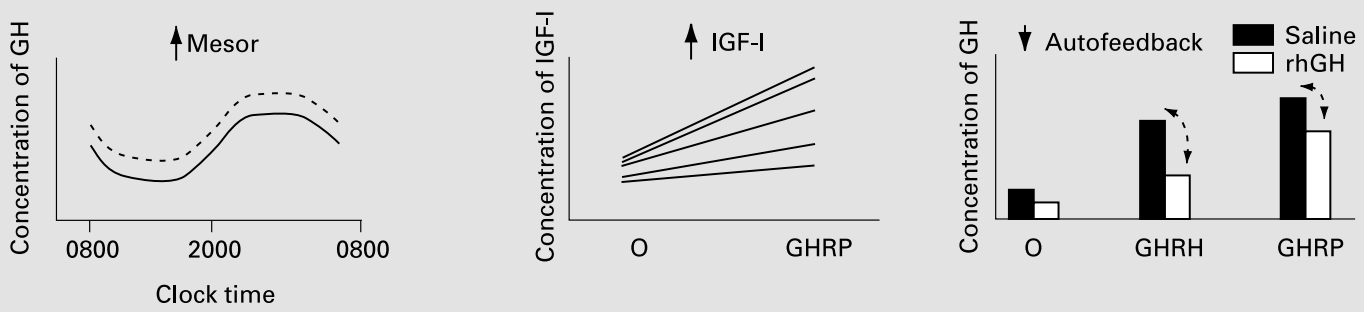

Fig. 3. a The impact of puberty in boys and girls on the mass of GH secreted per burst $(\mu \mathrm{g} / \mathrm{l})$. GH output was monitored by chemiluminescence assay of serum samples collected at 5-min intervals for $12 \mathrm{~h}$. Data show the extreme range, interquartile boundaries and median values. The absolute range of burst mass was 40 -fold among individuals. The mass of hormone secreted per burst is the time integral of the underlying (deconvolved) secretory pulse. Burst frequency and GH half-life do not change in puberty. Reproduced, with permission, from Veldhuis et al. [36]: ${ }^{\odot}$ The Endocrine Society. b Multifold mimicry of pubertal GH outflow induced by constant intravenous infusion of a potent, synthetic, hexapeptide analogue of ghrelin (GHRP-2 [1 $\mu \mathrm{g} / \mathrm{kg}]$ ) intravenously over $24 \mathrm{~h}$. Subpanels give measured outcomes of GHRP-2 drive. Blood was collected every $10 \mathrm{~min}$ beginning at $08.00 \mathrm{~h}$ (time zero). Technical explanations follow in the text concerning changes in pattern irregularity (approximate entropy), the 24-hour rhythmic mean concentration of GH (mesor), plasma concentration of IGF-I and autofeedback on the GHRP-2 stimulus. 
Fig. 4. a Concept of deconvolution analysis to unravel the components of hormone concentration peaks into their underlying secretion (S) and kinetic contributions. b Example of stable kinetics of recombinant human (rh)GH infused across three major strata of pubertal development in boys. Knowledge of the $\mathrm{GH}$ distribution volume is important, as deconvolution secretory burst mass and amplitude and secretion rates are normalized to unit volume of distribution.

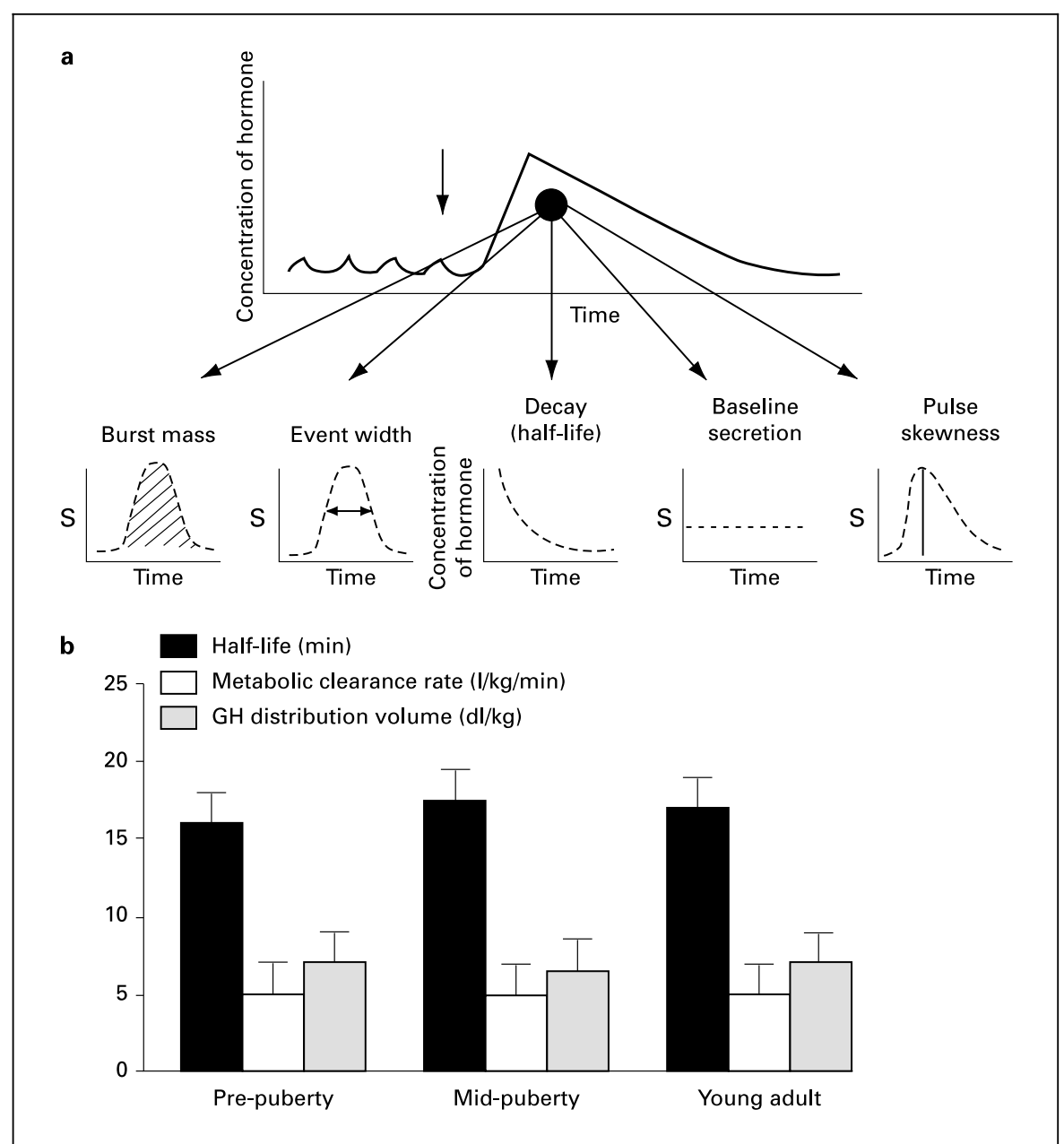

\section{Somatostatin: Inhibitory and Facilitative Roles}

The anterior pituitary gland expresses the five primary somatostatin receptor (SSTR) gene transcripts in the rat and human (yet not so evidently in the sheep) $[21,37,38]$. SSTR-1, SSTR-2 and SSTR-5 predominate. The arcuate nucleus manifests both SSTR-1 and SSTR-2 gene transcripts in approximately $15 \%$ of GHRH-secreting neurons in the adult male rat. Subtype-specific SSTR expression is sexually dimorphic, i.e. there is a large number of SSTR-1 in the arcuate nucleus and SSTR-2 predominates in the pituitary gland in males in comparison with females [39].

Intermittent exposure to somatostatin, although initially viewed as paradoxical, sensitizes somatotrope cells to stimulation by GHRH in vitro and in vivo [35, 40]. The outcome is an elevation in GH secretory burst mass, which may be measured directly in vitro through perifusion and indirectly in vivo by deconvolution analysis (fig. 4). This positive interaction is important physiologically as repeated administration of a linear hexapeptidyl SSTR antagonist inhibits weight gain and linear growth in the immature male rat [25]. From a mechanistic viewpoint, somatostatin facilitates GH secretion through both the pituitary gland and hypothalamus. In somatotrope cells, somatostatin: (1) blocks the release but not the de novo biosynthesis of $\mathrm{GH}$, thus favouring accumulation of releasable GH stores; (2) activates cellular phosphatases, which may mediate resensitization of the GHRH receptor; and (3) bidirectionally autoregulates cognate gene expression by rapid stimulation and delayed repression $[1,41]$. In the arcuate nucleus, somatostatin: (1) up-regulates SSTR-2 (an autostimulatory pathway) and downregulates SSTR-1 (an autoinhibitory pathway); and (2) represses GHRH outflow [42].

Both consecutive exposure to somatostatin and withdrawal of somatostatin cause a rebound-like pulse of $\mathrm{GH}$ 
Fig. 5. Illustration of approximate entropy as a statistical measure of graded subpattern disruption despite preservation of coarse structure (seen here as a simple cosine rhythm). More disorderly neurohormone release signifies deterioration of feedback and/ or feedforward control within the ensemble. Autonomous tumoural secretion, exogenous GHRH and/or GHRP-2 stimulation, defective GHRH-receptor signalling and IGF-I feedback withdrawal induce highly irregular secretion of $\mathrm{GH}$, whereas infusions of somatostatin and rhIGF-I by way of enforced feedback endow more reproducible subpatterns of GH outflow. Reproduced, with permission, from Hartman et al. [43]. Permission conveyed through the Copyright Clearance Center.

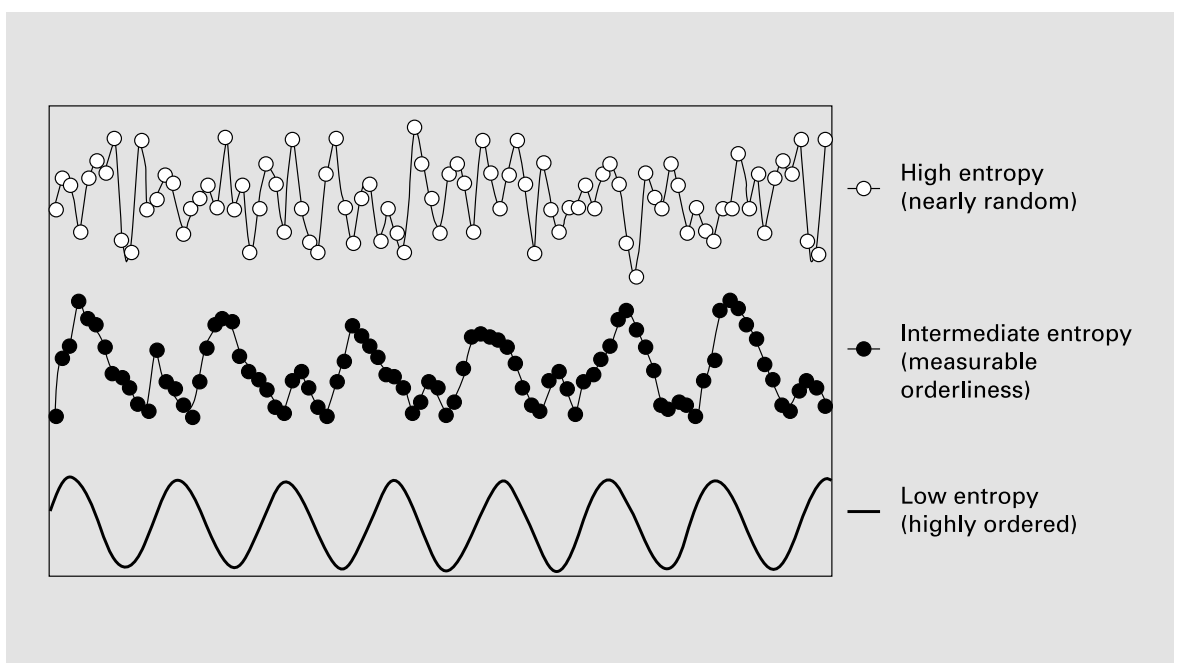

secretion. A possible basis for this in vivo event would involve a sequential four-part mechanism, for example:

(1) Pituitary accumulation of releasable GH stores by the blockade of exocytosis by somatostatin.

(2) Recovery of somatotrope GHRH-receptor sensitivity by activation of phosphatases.

(3) Restraint of hypothalamic somatostatin release during the rebound phase by removal of somatostatinergic autoneuronal stimulation via SSTR-2.

(4) Simultaneous induction of arcuate-nucleus GHRH secretion by withdrawal of somatostatinergic inhibition.

Regarding this last point, a single injection of a somatostatin analogue (octreotide) in the conscious ram represses and then (on octreotide removal) stimulates hypothalamic GHRH release into hypophysial-portal blood. In a functional context, passive immunoneutralization of GHRH activity in the adult male rat antagonizes rebound GH release [1].

The rebound burst of GH secretion is limited. The suppression of GH release when systemic concentrations of somatostatin fall could originate via a twofold mechanism involving interneuronal and central nervous system (CNS)-pituitary regulation. In particular, somatostatin withdrawal would predictably suppress SSTR-1-mediated autoneuronal inhibition, thus releasing hypothalamic somatostatin from SSTR-1 cells. Somatostatin is able to suppress GHRH outflow and block GH exocytosis, and, consequently, terminate the burst. GHRH (like GH), however, induces the release of hypothalamic somatostatin both in vivo and in vitro. The somatostatin restraint that would follow would initiate a new cycle of GH store accumulation, somatotrope resensitization to GHRH and inhibition of GHRH secretion. This type of intrahypothalamic scenario may be crucial to GH-pulse regeneration within a multipeak volley. The proposed series of events differs notably from concentration-dependent autofeedback by systemic GH. Blood-borne GH appears to induce periventricular-nuclear somatostatin secretion after a more prolonged time delay and with greater persistence than intrahypothalamic GHRH. Slower onset and offset of peripheral GH-mediated autoinhibition would reflect the need for CNS uptake, circulatory elimination and interneuronal tissue-fluid dissipation of the GH signal. This long-loop (systemic-CNS) autoinhibitory pathway may enforce the intervolley nadir in which GH secretion becomes undetectable in the adult male rat, but is measurable by immunofluorometry and immunochemiluminometry in the human [1]. In contrast, the adult female rodent exhibits substantial (but incomplete) escape from GH-driven autorepression. The implications of the previous regulatory interactions can be explored in simplified biomathematical constructs. Such formulations, which include key relevant time-delayed linkages, forecast gender-relevant automaticity (self-renewal) of hypothalamic GHRH and hypophysial GH pulses [2, 3]. A broad statistical tool 'approximate entropy' provides a non-invasive measure of adaptations in the overall regulatory linkages within a neuroendocrine ensemble (fig. 5).

The main connections between GHRH, somatostatin and GH are stabilized by complex regulatory redundancies. For example, other analyses have revealed temporally biphasic autoregulation of pituitary SSTRs, induction of pituitary SSTR-1 and SSTR-2 by GHRH and GH [24], and GH-dependent down-regulation of pituitary SSTR-2 

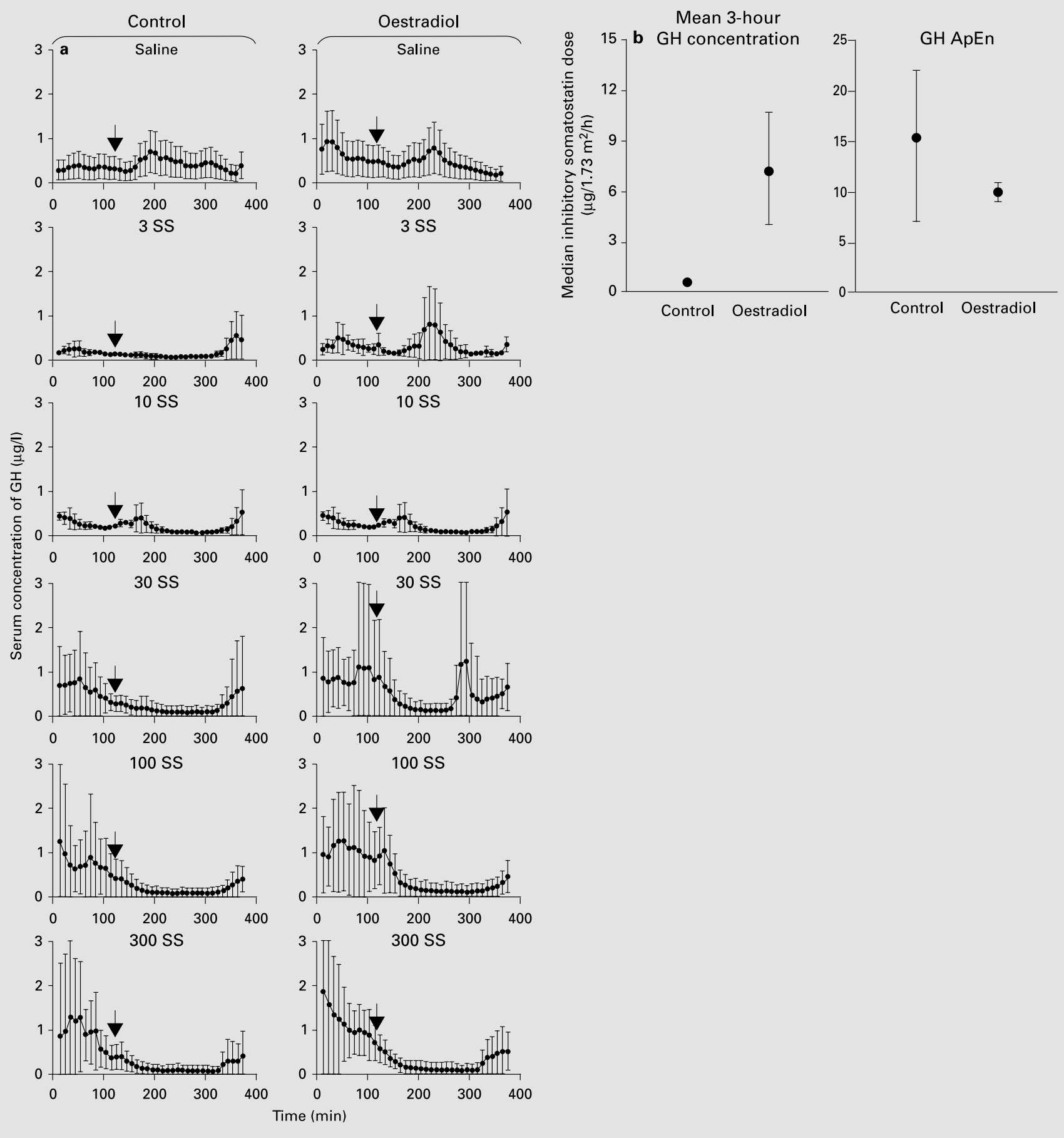

Control Oestradio

Control Oestradiol 


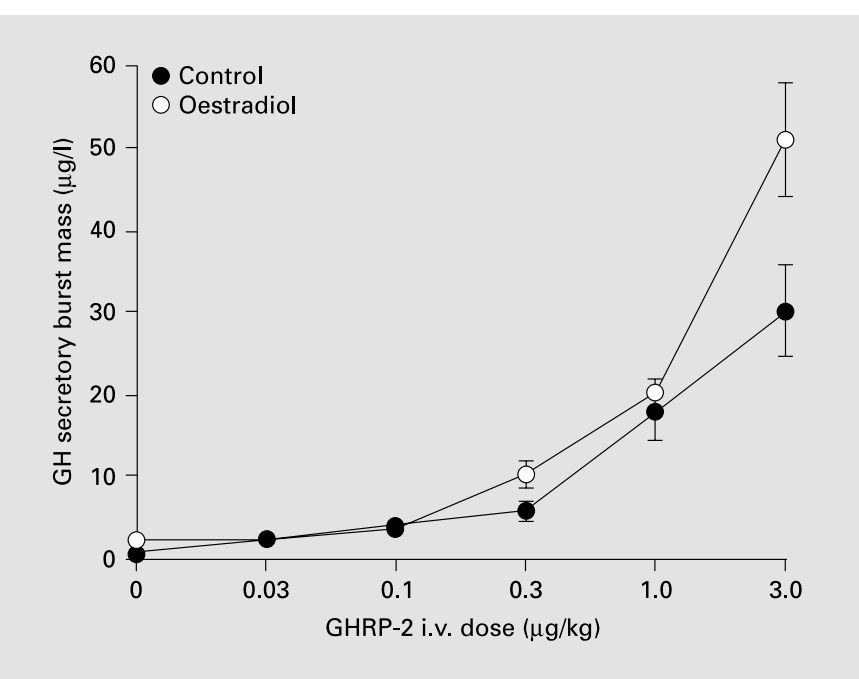

Fig. 7. Oestradiol potentiates dose-dependent stimulation of GH secretion by GHRP-2 in post-menopausal women. Adapted, with permission, from Anderson et al. [59]: ${ }^{\odot}$ The Endocrine Society.

and up-regulation of SSTR-5 gene transcripts. The precise implications and physiological regulation of such homologous and heterologous interactions across development are unclear.

Oestradiol stimulates transcriptional activity of the human SSTR-2 gene promoter in pituitary and breast cancer cells in vitro, and induces SSTR-2 and SSTR-3 gene expression (and somatostatin binding) in the rodent pituitary gland and arcuate nucleus in vivo [38, 44]. In contrast, oestrogens reduce the abundance of pituitary SSTR-1 and SSTR-5 mRNA [38]. The down-regulation of SSTR-5, if applicable to the human, could account for the ability of short-term replacement of oestradiol to antagonize inhibition by exogenous somatostatin in post-menopausal women (fig. 1b, fig. 6) [45].

\section{GHRP/Ghrelin: Unique Secretagogic, Appetitive and Metabotropic Peptides}

GH-releasing peptides were first synthesized more than 20 years ago in the laboratory of Cyril Y. Bowers. Early compounds were oligopeptide derivatives of metenkephalin, which stimulated in vitro GH secretion by two- to three-fold at nanomolar concentrations. The GHRP receptor was cloned, expressed and mapped topographically in 1996 [1], and a gene encoding the endogenous ligand, ghrelin, was sequenced from the rat and human stomach 3 years later [10, 11, 16, 31, 46, 47].
Ghrelin is a 28 -amino-acid peptide requiring fatty acylation of the N-terminal $\mathrm{Ser}^{3}$ residue (e.g. non-exclusively by octanoylic acid) for biological activity. A naturally occurring des-Gln ${ }^{14}$-ghrelin (27-amino-acid peptide) is also biologically active, but its physiological role is not defined.

Diverse GHRP-receptor agonists are able to:

(1) synergize with GHRH in vivo but not in vitro (except in some perifusion systems)

(2) oppose certain hypothalamic actions of somatostatin

(3) stimulate release of arcuate-nucleus GHRH

(4) partially overcome GH autonegative feedback

(5) increase pituitary GH gene expression after prolonged administration in the immature (but not adult) animal

(6) stimulate somatotrope expression of the pit- 1 gene (a pituitary-specific cytodifferentiation-enhancing transcription factor)

(7) trigger secretion of prolactin and adrenocorticotropin transiently

(8) exert motilin-like gastroprokinetic effects directly and stimulate peptic acid secretion indirectly via CNS pathways

(9) serve as potent central appetitive signals (orexigens)

(10) act as cardiotropic agents

(11) antagonize (acutely) or facilitate (chronically) peripheral glucose disposal

(12) block $\beta$-cell insulin secretion in vitro and augment insulin release in vivo

(13) inhibit fat oxidation directly, thus promoting adipocyte hypertrophy

(14) deplete intra-abdominal fat indirectly by stimulating pulsatile GH secretion [10, 11, 13, 18, 44-53].

\section{Ghrelin}

Immunoreactive (but not necessarily commensurately bioactive) ghrelin circulates at concentrations of 200$650 \mathrm{pmol} / 1$ in the rat and human. Higher values are approximately the same magnitude as the in vitro ligandreceptor equilibrium dissociation constant $[11,20]$. The concentrations of ghrelin fall post-prandially and in obesity, and rise during fasting, after weight loss or gastrectomy and in anorexia nervosa [54, 55]. Calorific restriction unmasks the diurnal rhythmicity of the concentrations of ghrelin. In young adults, intravenous infusion of ghrelin $(5.0 \mathrm{pmol} / \mathrm{kg} / \mathrm{min})$ for $20 \mathrm{~min}$ increases the concentrations of ghrelin by two- to three-fold, stimulates GH secretion by $50 \%$ of maximal output and enhances appetite compared with saline [56]. Clinical data are consistent with inferences in a transgenic model of molecular silenc- 
Fig. 8. Impact of GHRP-2, GHRH and placebo on pulsatile $\mathrm{GH}$ secretion calculated by deconvolution analysis. Individual GH-concentration profiles were obtained by sampling blood every $10 \mathrm{~min}$ for $24 \mathrm{~h}$. Data are from a post-menopausal volunteer studied on six occasions in randomly assigned order before and after oestradiol replacement [30, 58]. Each peptide was infused continuously at a rate of $1 \mu \mathrm{g} / \mathrm{kg} / \mathrm{h}$ intravenously for $24 \mathrm{~h}$.

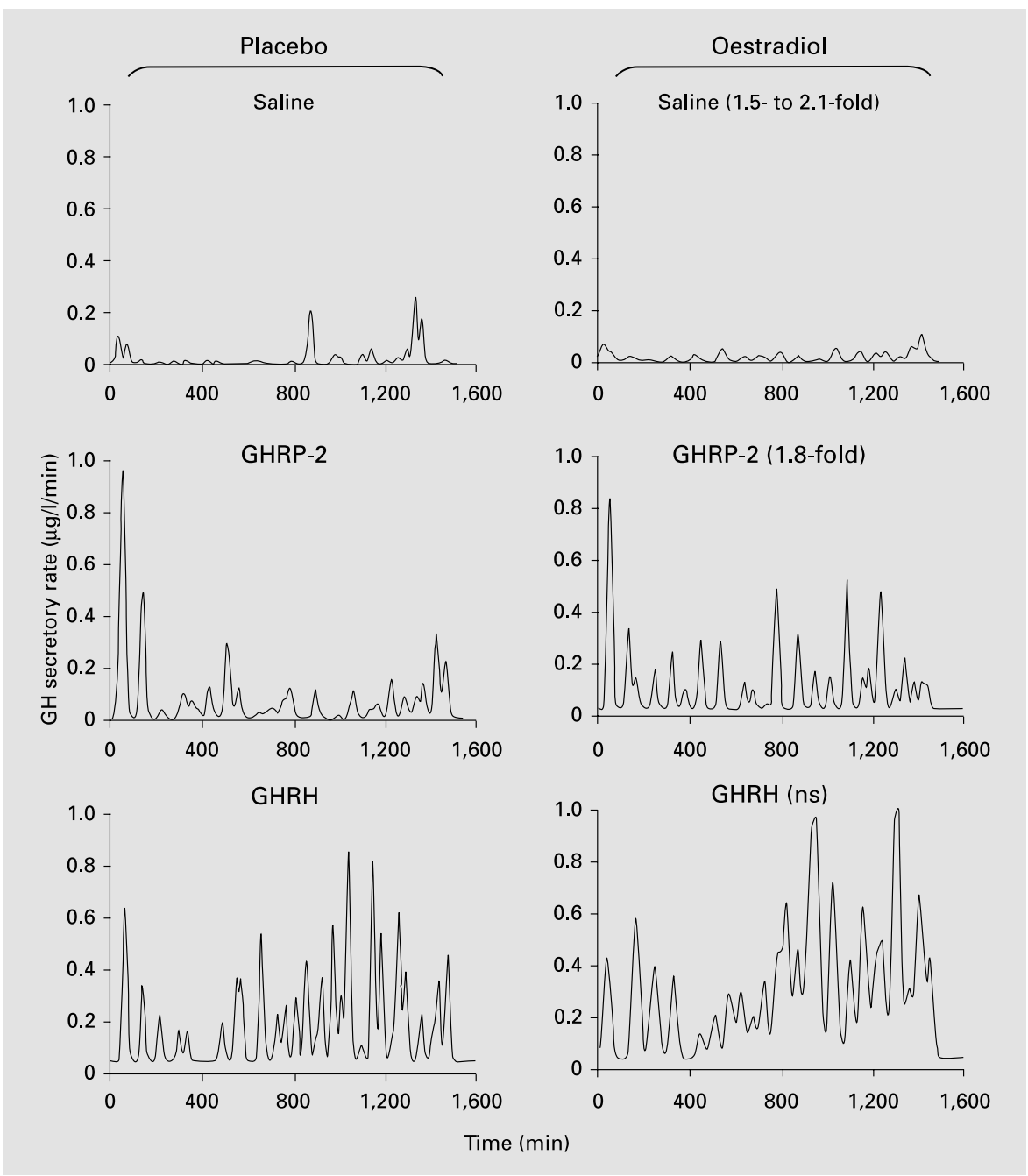

ing of the hypothalamic GHRP receptor. Affected mice of either sex eat sparingly, gain weight at a poor rate and acquire little intra-abdominal fat. Only the female transgenic animal exhibits a significant reduction in pulsatile GH secretion and serum concentrations of IGF-I [57]. The latter gender contrast is not well explained, despite several examples of sex differences in GHRP receptor expression. In the human, the oestradiol-replete state acutely potentiates the stimulation of $\mathrm{GH}$ secretion by GHRP (fig. 7, 8) [56].

\section{GHRP}

GHRP and GHRH act synergistically in the presence of a functional hypothalamo-pituitary nexus. Peptide synergy reflects the complementary and convergent effects of these two secretagogues, which are:
(1) GHRP evokes the release of GHRH from the arcuate nucleus in the sheep and opposes hypothalamic inhibitory effects of somatostatin in the rat.

(2) GHRP down-regulates, whereas GHRH up-regulates, ghrelin and the cognate receptor in the pituitary gland.

(3) GHRP induces GH gene expression after extended administration in the immature animal only (i.e. not adult) and stimulates maximal GH secretion in puberty, whereas GHRH drives GH gene transcription promptly at all ages and elicits maximal GH secretion earlier in life.

(4) Feedforward by GHRP compared with GHRH is resistant to $\mathrm{GH}$ autofeedback.

(5) GHRH and GHRP activate distinct cellular receptor-effector signalling pathways, which intersect more subtly at several distal loci [18, 60-62]. 
Administration of GHRP-receptor agonists in nearmaximal and intermittent doses produces rapid response desensitization in vitro and in vivo. On the other hand, delivery of a submaximal effective (or near-stimulus threshold) dose frequently or continuously sustains pulsatile GH secretion and elevates serum concentrations of IGF-I for at least 3-6 months; slows down fasting-associated nitrogen wasting; augments lean-tissue mass; reduces visceral adiposity; acutely antagonizes and chronically facilitates insulin action (the latter emerges as intraabdominal fat mass decreases under GH stimulation); opposes oxidation of fat in adipocytes by $\mathrm{GH}$ receptorindependent mechanisms; and promotes bone remodelling $[12,18,58,63-70]$. The impact of continuous intravenous infusion of GHRH or GHRP-2 separately for $24 \mathrm{~h}$ is illustrated in figure 8.

Interventional trials are being used to evaluate the growth-promoting efficacy of GHRP-receptor agonists in clinically pre-pubertal children with idiopathic short stature and non-destructive GH-deficient states. In available investigations, hexapeptides (hexarelin or GHRP-2) or the non-peptidyl GHRP mimetic, MK-0677 (ipamorelin), were administered intranasally, orally or subcutaneously 1-3 times daily for 6 months or more. These agents increase serum concentrations of IGF-I, GH and IGF-binding protein 3 (IGFBP-3) into the normal range. Responses tend to be biphasic over time, with an initial two- to threefold elevation, followed by a $30-40 \%$ decline to values that continue to exceed pre-study baseline determinations significantly. Collective data from 30 children in five studies produced cohort-mean annualized height velocities at 6 months of $6.0-8.3 \mathrm{~cm} /$ year (aggregate $\mathrm{p}<0.001$ vs. basal growth records) $[64,65,67,68]$.

In a prospective clinical study involving healthy, older (physiologically hyposomatotropic) adults, GHRP-2 was delivered by continuous subcutaneous infusion $(1 \mu \mathrm{g} /$ $\mathrm{kg} / \mathrm{h}$ ) for 1-3 months [69]. Detailed analyses of 24-hour $\mathrm{GH}$ release profiles showed tripartite stimulation of pulsatile, entropic (feedback-sensitive irregularity) and 24hour rhythmic GH secretion. Concentrations of IGF-I increased significantly and remained at this level for 90 days. Daily pulsatile GH production rates (calculated by deconvolution analysis) increased initially by $2-3$ times baseline values (at 1 week) and then decreased gradually to 1.5-2 times baseline values (for 3 months). Of note, peripheral concentrations of IGF-I did not fall as GH output reset to an intermediate value; the basis for this dissociation is not established, but one mechanism may be more effectual $\mathrm{GH}$ drive to the liver and other organs resulting from a GH secretory pattern similar to that seen in puberty. The $30-35 \%$ decline in mean GH concentrations may reflect negative feedback by $\mathrm{GH}$ and IGF-I on the hypothalamo-pituitary unit [69]. An important insight in this study is that unvarying low-dose GHRP-receptor agonism (unlike continuous GnRH receptor stimulation) augments and maintains a physiological pattern of higher amplitude, more entropic and nycthemerally rhythmic GH secretion for at least 90 days. Continual intravenous infusion of GHRP-2 and/or GHRH for $24 \mathrm{~h}$ also elevates concentrations of IGF-I and enforces a pubertal-like pattern of $\mathrm{GH}$ secretion (fig. 1b, fig. 8) $[58,63]$.

The neuroendocrine phenotype induced by constant low-dose GHRP-2 infusion mirrors that of puberty. Specific similarities include: (1) increased GH secretory-burst mass and thereby greater incremental and maximal GH peaks; (2) a fixed GH pulse frequency and half-life; (3) a more irregular pattern of $\mathrm{GH}$ secretion (measured by elevated approximate entropy), which denotes strong feedback adaptations; (4) heightened diurnal GH rhythmicity; and (5) systemically elevated concentrations of IGF-I [36, $71]$.

The significant (1.5- to 3-fold) rise in mean serum concentrations of GH and IGF-I resulting from near-constant stimulation of GHRP would be predicted to repress GH secretion by autoinhibition. Thus, it would be of interest to investigate the basis for partial feedback escape in both settings. Possible adaptive mechanisms in this unique clinical context include: (1) a reduction in negative feedback caused by a mid-physiological (rather than pharmacological) elevation of GH and IGF-I; and/or (2) limited down-regulation of the GHRP-response pathways by continuous low-dose agonist exposure. Regarding the last point, repeated intragastric administration of a small yet effective dose of a non-peptidyl GHRP mimetic in pigs increases pulsatile GH secretion, the approximate entropy of GH release and plasma concentrations of IGF-I over a period of 5 days. In contrast, a threefold higher (nearmaximally effective) dose of the same agonist represses GH secretion on the second day [72].

\section{Developmental Control of GH Secretion}

The secretion and activity of GH, IGF-I, GHRH, GHRP and somatostatin differ in several respects in utero, and during infancy, childhood, puberty and adulthood. First, pulsatile GH secretion increases markedly, but transiently, in the newborn in association with initially reduced systemic concentrations of IGF-I [73, 74]. Sec- 
ond, GHRH up-regulates and down-regulates the cognate pituitary receptor in the immature and adult rat, respectively [20, 32]. Third, post-aromatization oestrogen induces periventricular somatostatin gene expression in the first 5 days of post-natal life, but not consistently in the pre-pubertal, pubertal or adult animal. Finally, oestradiol stimulates GHRH gene expression in the arcuate nucleus of the infantile rat, but represses the same endpoint in the adult animal $[14,75]$. Oestrogenic effects may be exerted by the OR- $\alpha$ gene, which is expressed in the majority $(>65 \%$ ) of single (adult) GHRH neurons. The genetic programs that control developmental expression of OR- $\alpha$ in this area are currently undefined.

\section{GH Autonegative Feedback: Mechanisms of Autoinhibition and Escape}

Time-delayed feedforward and feedback interactions among GH, GHRH and somatostatin offer self-renewable GH pulsatility in simplified biomathematical formulations [2, 3]. All three components - feedforward, feedback and time delay - are critical elements in driving pulse automaticity. In this framework, ghrelin serves as an amplifier from pituitary and systemic sources. The ghrelin gene is definitively expressed in the anterior pituitary gland. At present, however, immunoreactive ghrelin, but not the ghrelin transcript, is identifiable in disparate hypothalamic neurons. Accordingly, neurons might in principle accumulate (and not synthesize) the peptides.

$\mathrm{GH}$ autofeedback in the adult male rodent is not required in the overlap of the mechanistic pathway. Two of the requirements for this pathway are:

(1) a functional GH receptor in the brain coupled positively to somatostatin secretion, as observed in antisense receptor-silencing experiments in the rat [76];

(2) the SSTR-2 within the hypothalamo-pituitary unit, as established in the transgenic mouse [21,77].

SSTR-2 could participate in this pathway by mediating somatostatinergic autoneuronal facilitation in the hypothalamus (thereby heightening somatostatin outflow during GH autofeedback) and in blocking granule exocytosis by somatotrope cells. Concomitantly, GH represses the synthesis and secretion of GHRH, thereby withdrawing the feedforward drive $[2,3,78]$.

The female rat maintains minimal, but detectable, $\mathrm{GH}$ autoinhibition. This sex difference is caused mainly by the reduction of GH-inducible somatostatin outflow [1] and may reflect, in part, the ability of oestradiol to downregulate the $\mathrm{GH}$ receptor gene in the arcuate nucleus. Tes-

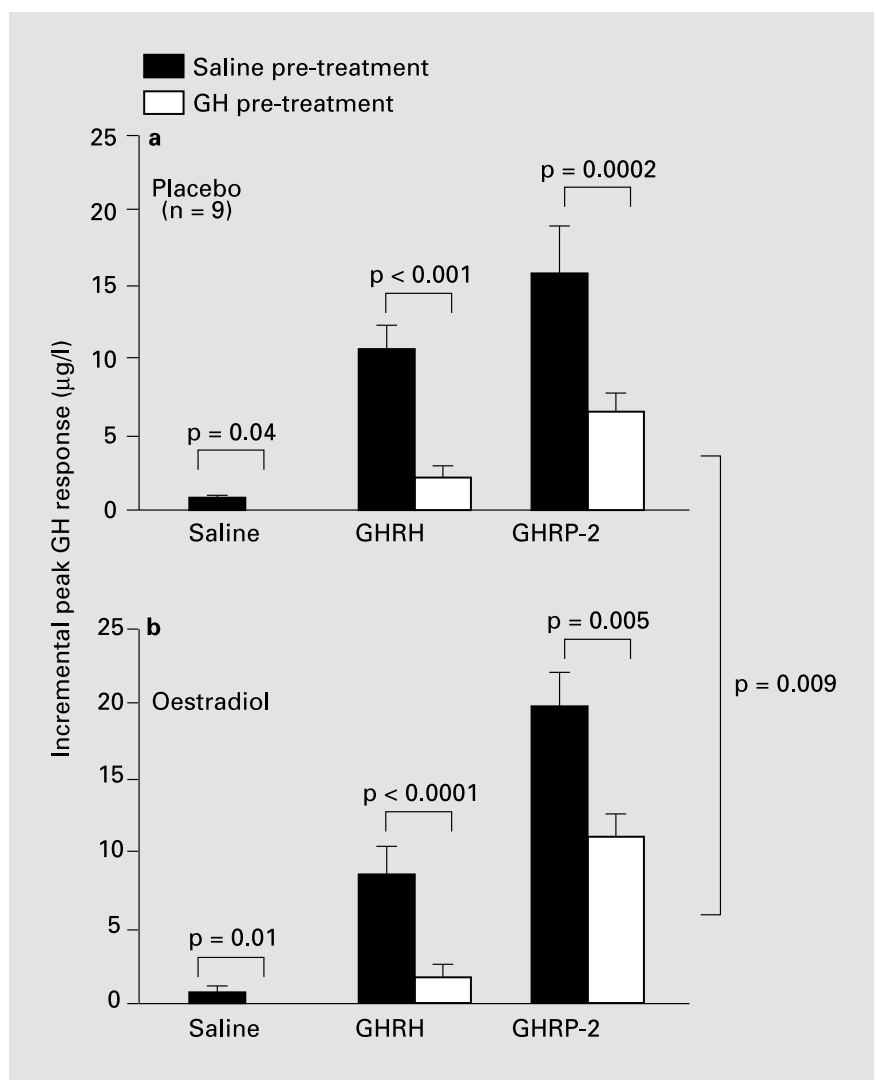

Fig. 9. Oestradiol suppresses autonegative feedback by a single bolus of rhGH on GHRP-2 (but not basal or GHRH)-stimulated GH secretion in post-menopausal individuals. Panels illustrate feedback repression imposed by a pulse of rhGH on basal, GHRH- and GHRP2-stimulated GH release following short-term supplementation of post-menopausal women with a oral placebo or b oestradiol repletion. Reproduced, with permission, from Anderson et al. [79]: ${ }^{\circ}$ The Endocrine Society.

tosterone, however, induces SSTR-2 in the pituitary gland more effectively than oestradiol in vivo, thus accentuating the interpulse suppression of GH release under somatostatin outflow in the male rodent. In humans, oestrogen selectively suppresses $\mathrm{GH}$-induced autonegative feedback on the GHRP-2 (but not basal, exercise or GHRH) stimulus (fig. 9) [79]. Such selectivity may occur through upregulation of the GHRP receptor gene and can be observed in transcription assays in vitro.

In adolescence, GH secretion is not repressed by highamplitude GH pulses and elevated systemic concentrations of IGF-I [71]. One recent analysis disclosed two possible mechanisms to explain this paradox in mid-pubertal boys: (1) the marked suppression of GH pulsatility by a single intravenous pulse of recombinant human (rh) $\mathrm{GH}$ 

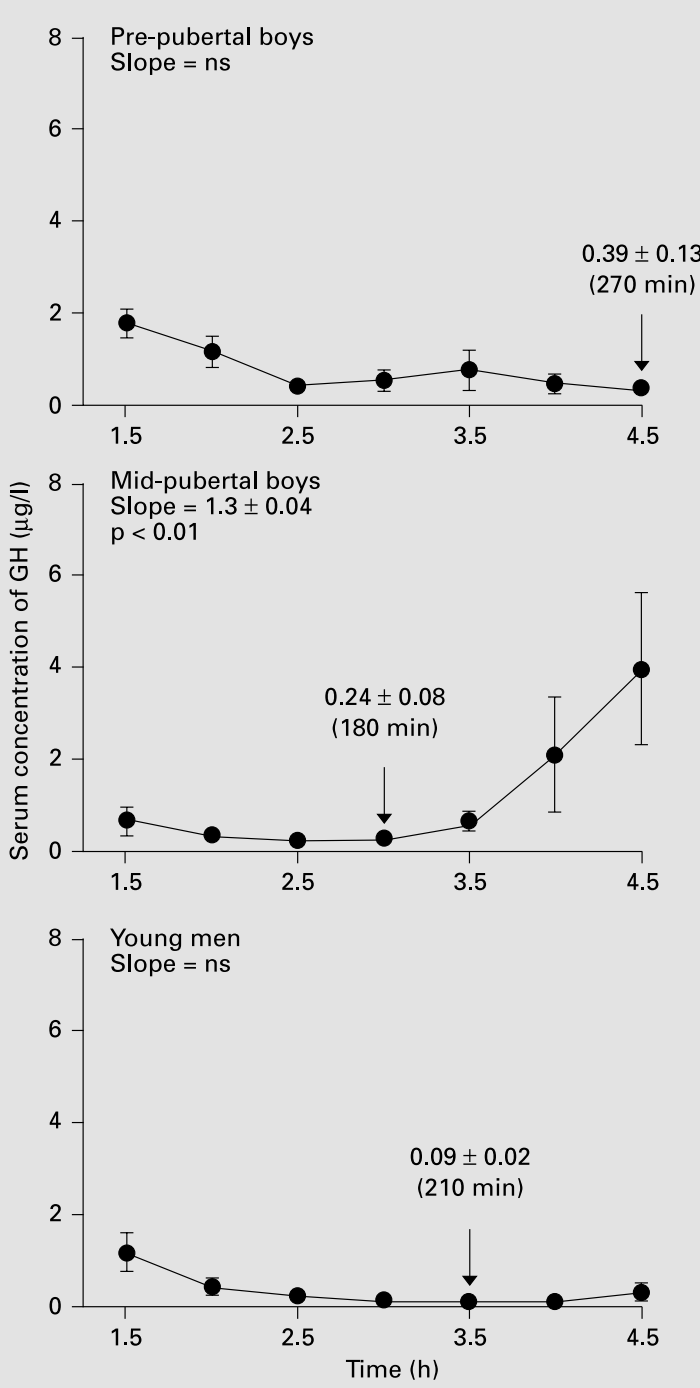

Fig. 10. Time course of escape from autofeedback inhibition of GH release in three developmental strata of boys. A single pulse of rhGH was injected at time zero (before the illustrated record begins). Adapted, with permission, from Richmond et al. [80]: ${ }^{\odot}$ The Endocrine Society.

infused over a 6-min period $2 \mathrm{~h}$ earlier; and (2) a more rapid recovery of $\mathrm{GH}$ secretion following the induced nadir in mid-pubertal boys than in pre-pubertal boys or young men (fig. 10). These distinctions operate in the face of equivalent feedback inhibition of an exogenous GHRH stimulus [80]. Prominent autoinhibition of pulsatile GH secretion (defined in absolute $[\mu \mathrm{g} / \mathrm{l}]$ and fractional [\%] terms) in mid-adolescence could indicate a unique
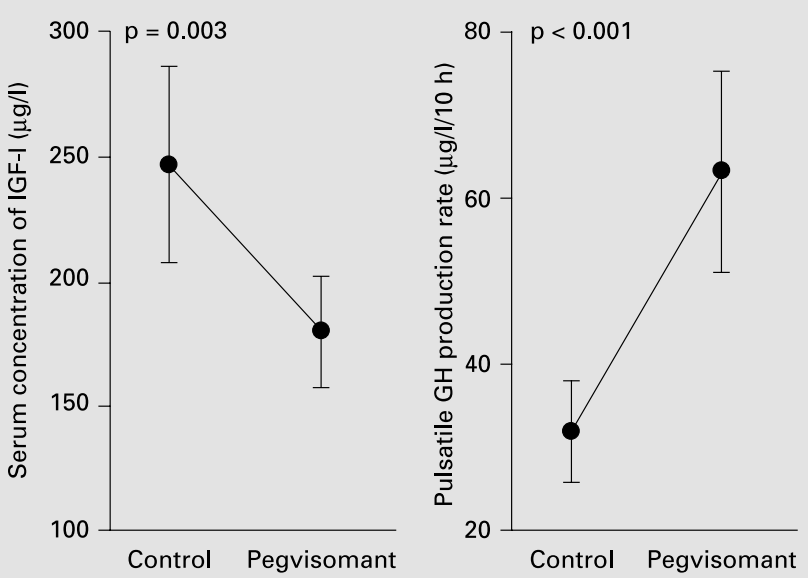

Fig. 11. Reciprocal effects of a selective GH-receptor antagonist (pegvisomant) to deplete concentrations of IGF-I and release GH secretion in healthy young adults. Adapted, with permission, from Veldhuis et al. [81]: ${ }^{\circ}$ The Endocrine Society.

inhibitory susceptibility of arcuate-nucleus GHRH release to GH-imposed negative feedback. Accelerated escape of GH output after maximal suppression could indicate heightened GHRH and GHRP drive and/or an abbreviated duration of $\mathrm{GH}$-induced somatostatin outflow [80]. Equivalent feedback inhibition of exogenous GHRH stimulus would indicate similar GH-induced somatostatin restraint before, during and after puberty.

Infusion of rhIGF-I inhibits pulsatile GH secretion in the rat and human. A novel strategy has been applied recently to reveal feedback suppression by systemic IGF-I. In this clinical study, IGF-I depletion was achieved through a single subcutaneous injection of pegvisomant $1 \mathrm{mg} / \mathrm{kg}$ (a selective $\mathrm{GH}$ receptor antagonist peptide) and compared with saline [81, 82]. Pegvisomant stimulated a 1.8-fold rise in overnight pulsatile and basal GH secretion while inducing a $32 \%$ reduction in serum concentrations of IGF-I within $72 \mathrm{~h}$ (fig. 11). The degree of unconstrained feedback was compared by sex in the cohort of nine men and seven women studied. Kinetic analyses of the data showed that GH receptor blockade does not alter the halflife of secreted $\mathrm{GH}$ or infused rhGH despite the attainment of a mean serum concentration of pegvisomant that was 3,000-fold higher than that of GH. Concentrations of GH also increase in successfully treated (IGF-I depleted) patients with acromegaly. GH kinetics are normal so the elevation in $\mathrm{GH}$ would indicate the preservation of feedback reactivity by a subpopulation of somatotropes. 


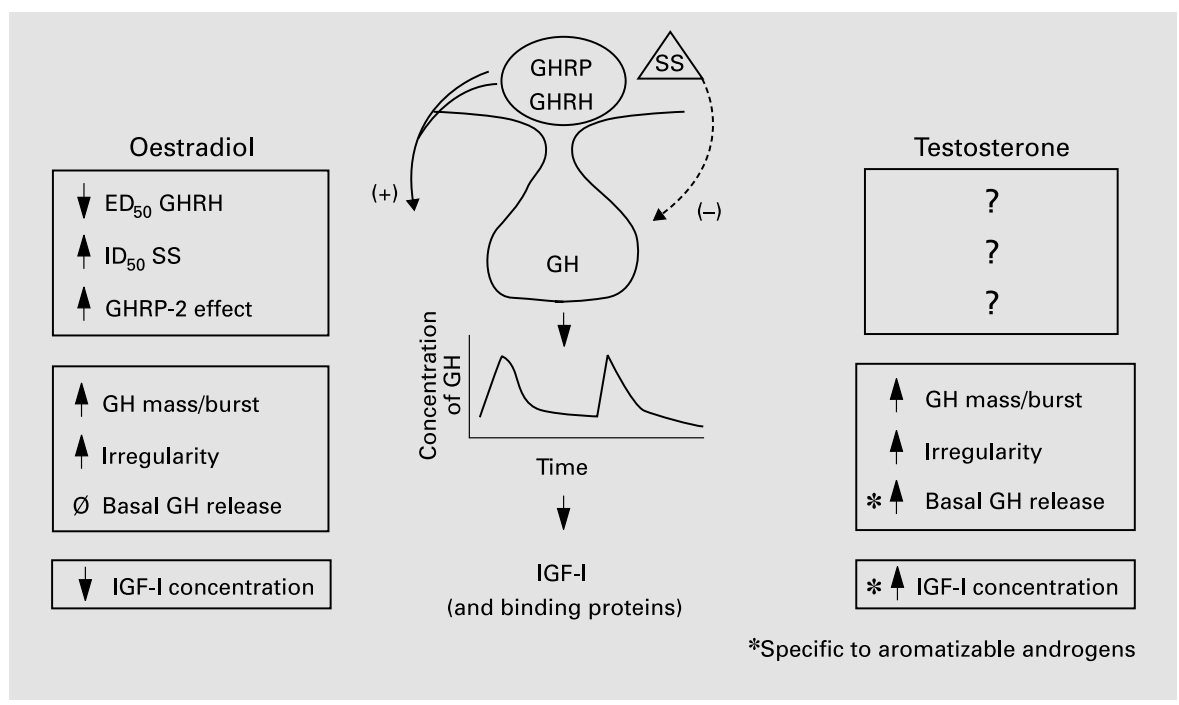

Fig. 12. Left column Composite impact of oestradiol on exogenous drive by GHRH, somatostatin (SS) and GHRP-2 in post-menopausal individuals (top left box). Oestrogen supplementation augments GH secretory-burst mass and the irregularity of release patterns without altering deconvolution-estimated true (non-pulsatile) basal GH secretion (left middle box). Oestradiol repletion also depletes IGF-I, elevates IGFBP-1 and does not alter concentrations of IGFBP-3. The first two adaptations predictably limit free IGF-I availability, which would mute negative feedback [79]. Middle column Schema of primary effector actions within GH-IGF-I axis. Right column Lack of equivalent single-effector studies of testosterone. Distinct mechanistic contrasts between testosterone and oestradiol, i.e. only testosterone stimulates computed basal (non-pulsatile) GH secretion and elevates serum concentrations of IGF-I [30, 58, 59, 79, 81, 83].

\section{Summary}

The regulation of $\mathrm{GH}$ secretion proceeds via a minimally tripeptidyl ensemble, comprising a combined input of GHRH, GHRP and somatostatin. Sex-steroid hormones, as well as other factors, modulate the synthesis, secretion and reception of the primary signals listed above (fig. 12). Collaborative experiments in molecular biology, cellular biochemistry and integrative physiology are beginning to unravel the mechanisms that coordinate the activity of this putative ensemble over the human lifetime.

\section{Acknowledgements}

The author would like thank Jean Plote for her excellent editorial assistance. This work was supported in part by the National Center for Research Resources via General Clinical Research Center grant M01 RR00585 to the Mayo Clinic and National Institutes of Health grants ROI AG 14799 and AG 19695.

\section{References}

1 Giustina A, Veldhuis JD: Pathophysiology of the neuroregulation of GH secretion in experimental animals and the human. Endocr Rev 1998;19:717-797

2 Farhi LS, Straume M, Johnson ML, Kovatchev BP, Veldhuis JD: A construct of interactive feedback control of the $\mathrm{GH}$ axis in the male. Am J Physiol 2001;281:R38-R51.

3 Farhy LM, Straume M, Johnson MJ, Kovatchev B, Veldhuis JD: Unequal autonegative feedback by growth hormone $(\mathrm{GH})$ models the sexual dimorphism in GH secretory dynamics. Am J Physiol 2002;282:R753-R764
4 Le Roith D, Bondy C, Yakar S, Liu JL, Butler A: The somatomedin hypothesis: 2001. Endocr Rev 2001;22:53-74.

5 Frohman LA, Jansson J-O: Growth hormonereleasing hormone. Endocr Rev 1986;7:223253.

6 Jaffe CA, DeMott Friberg R, Barkan AL: Suppression of growth hormone $(\mathrm{GH})$ secretion by a selective GH-releasing hormone (GHRH) antagonist. J Clin Invest 1993;92:695-701.
7 Lumpkin MD, Gegro-Vilar A, McCann SM: Paradoxical elevation of growth hormone by intraventricular somatostatin: possible ultrashort-loop feedback. Science 1981;211:10721074.

8 Murakami Y, Kato Y, Kabayama Y, Inoue T, Koshiyama $\mathrm{H}$, Imura $\mathrm{H}$ : Involvement of hypothalamic growth hormone (GH)-releasing factor in GH secretion induced by intracerebroventricular injection of somatostatin in rats. Endocrinology 1987;120:311-316. 
9 Howard AD, Feighner SD, Cully DF, Arena JP, Liberator PA, Rosenblum CI, Hamelin M, Hreniuk DL, Palyha OC, Anderson J, Paress PS, Diaz C, Chou M, Liu KK, McKee KK, Pong SS, Chaung LY, Elbrecht A, Dashkevicz M, Heavens R, Rigby M, Sirinathsinghji DJS Dean DC, Melillo DG, van der Ploeg LH: A receptor in pituitary and hypothalamus that functions in growth hormone release. Science 1996;273:974-977.

10 Bowers CY, Chang J, Momany F, Folkers K: Effect of the enkephalins and enkephalin analogs on release of pituitary hormones in vitro; in MacIntyre I, Szelke M (eds): Molecular Endocrinology. Amsterdam, Elsevier Science, 1977, pp 287-292.

11 Asakawa A, Inui A, Kaga T, Yuzuriha H, Nagata T, Ueno N, Makino S, Fujimiya M, Niijima A, Fujino MA, Kasuga M: Ghrelin is an appetite-stimulatory signal from stomach with structural resemblance to motilin. Gastroenterology 2001;120:337-345.

12 Broglio F, Arvat E, Benso A, Gottero C, Muccioli G, Papotti M, van der Lely AJ, Deghenghi R, Ghigo E: Ghrelin, a natural GH secretagogue produced by the stomach, induces hyperglycemia and reduces insulin secretion in humans. J Clin Endocrinol Metab 2001;86:50835086.

13 Gianotti L, Maccario M, Lanfranco F, Ramunni J, Di Vito L, Grottoli S, Mueller EE, Ghigo E, Arvat E: Arginine counteracts the inhibitory effect of recombinant human insulin-like growth factor I on the somatotroph responsiveness to growth hormone-releasing hormone in humans. J Clin Endocrinol Metab 2000;85: 3604-3608

14 Mueller EE, Locatelli V, Cocchi D: Neuroendocrine control of growth hormone secretion. Physiol Rev 1999;79:511-607.

15 Aimaretti G, Corneli G, Razzore P, Bellone S, Baffoni C, Arvat E, Camanni F, Ghigo E: Comparison between insulin-induced hypoglycemia and growth hormone (GH)-releasing hormone + arginine as provocative tests for the diagnosis of $\mathrm{GH}$ deficiency in adults. $\mathrm{J}$ Clin Endocrinol Metab 1998;83:1615-1618.

16 Bowers CY: GH releasing peptides (GHRPs); in Kostyo J, Goodman H (eds): Handbook of Physiology. New York, Oxford University Press, 1999, pp 267-297.

17 Valetto MR, Bellone J, Baffoni C, Savio P, Aimaretti G, Gianotti L, Arvat E, Camanni F, Ghigo E: Reproducibility of the growth hormone response to stimulation with growth hormone-releasing hormone plus arginine during lifespan. Eur J Endocrinol 1996;135:568-572.

18 Bowers CY, Granda-Ayala R: GHRP-2, GHRH and SRIF interrelationships during chronic administration of GHRP-2 to humans. J Pediatr Endocrinol Metab 1996;9:261-270.

19 Vale WW, Vaughan J, Yamamoto G, Spiess J, Rivier J: Effects of synthetic human pancreatic (tumor) $\mathrm{GH}$ releasing factor and somatostatin, triiodothyronine and dexamethasone on $\mathrm{GH}$ secretion in vitro. Endocrinology 1983;112. 1553-1555.
20 Mayo KE, Miller T, DeAlmeida V, Godfrey P, Zheng J, Cunha SR: Regulation of the pituitary somatotroph cell by GHRH and its receptor. Recent Prog Horm Res 2000;55:237-266.

21 Tannenbaum GS, Zhang WH, Lapointe M, Zeitler P, Beaudet A: Growth hormone-releasing hormone neurons in the arcuate nucleus express both Sst 1 and Sst2 somatostatin receptor genes. Endocrinology 1998;139:14501453.

22 Aguila MC: Growth hormone-releasing factor increases somatostatin release and mRNA levels in the rat periventricular nucleus via nitric oxide by activation of guanylate cyclase. Proc Natl Acad Sci USA 1994;91:782-786.

23 Aguila MC: Somatostatin decreases somatostatin messenger ribonucleic acid levels in the rat periventricular nucleus. Peptides 1998;19: 1573-1579.

24 Park S, Kamegai J, Johnson TA, Frohman LA, Kineman RD: Modulation of pituitary somatostatin receptor subtype (sst1-5) messenger ribonucleic acid levels by changes in the growth hormone axis. Endocrinology 2000;141:35563563.

25 Baumbach WR, Carrick TA, Pausch MH, Bingham B, Carmignac D, Robinson ICAF, Houghten R, Eppler CM, Price LA, Zysk JR: A linear hexapeptide somatostatin antagonist blocks somatostatin activity in vitro and influences growth hormone release in rats. Mol Pharm 1998;54:864-873.

26 Magnan E, Cataldi M, Guillaume V, ConteDevolx B, Graziani N, Figaroli JC, Thomas F, Chihara K, Oliver C: Acute changes in growth hormone-releasing hormone secretion after injection of BIM 23014, a long acting somatostatin analog, in rams. Life Sci 1992;51:831-838.

27 Thomas GB, Cummins JT, Francis H, Sudbury AW, McCloud PI, Clarke IJ: Effect of restricted feeding on the relationship between hypophysial portal concentrations of growth hormone (GH)-releasing factor and somatostatin, and jugular concentrations of $\mathrm{GH}$ in ovariectomized ewes. Endocrinology 1991;128:1151-1158.

28 Veldhuis JD, Fletcher TP, Gatford KL, Egan AR, Clarke IJ: Hypophyseal-portal somatostatin (SIRF) and jugular venous growth hormone secretion in the conscious unrestrained ewe. Neuroendocrinology 2002;75:83-91.

29 Roelfsema F, Biermasz NR, Veldman RG, Veldhuis JD, Frolich M, Stokvis-Brantsma WH, Wit J-M: Growth hormone (GH) secretion in patients with an inactivating defect of the $\mathrm{GH}$-releasing hormone $(\mathrm{GHRH})$ receptor is pulsatile: evidence for a role for non-GHRH inputs into the generation of $\mathrm{GH}$ pulses. J Clin Endocrinol Metab 2000;86:2459-2464.

30 Evans WS, Anderson SM, Hull LT, Azimi PP, Bowers CY, Veldhuis JD: Continuous 24-hour intravenous infusion of recombinant human growth hormone (GH)-releasing hormone$(1,44)$-amide augments pulsatile, entropic, and daily rhythmic GH secretion in post-menopausal women equally in the estrogen-withdrawn and estrogen-supplemented states. J Clin Endocrinol Metab 2001;86:700-712.
31 Kamegai J, Tamura H, Shimizu T, Ishii S, Sugihara H, Oikawa S: Regulation of the ghrelin gene: growth hormone-releasing hormone upregulates ghrelin mRNA in the pituitary. Endocrinology 2001;142:4154-4157.

32 Webb CB, Vance ML, Thorner MO, Perisutti G, Thominet J, River J, Valae W, Frohman LA: Plasma growth hormone responses to constant infusion of human pancreatic growth hormone releasing factor. J Clin Invest 1984;74: 96-103.

33 Iranmanesh A, South S, Liem AY, Clemmons D, Thorner MO, Weltman A, Veldhuis JD: Unequal impact of age, percentage body fat, and serum testosterone concentrations on the somatotropic, IGF-I, and IGF-binding protein responses to a three-day intravenous growthhormone-releasing-hormone (GHRH) pulsatile infusion. Eur J Endocrinol 1998;139:59-71.

34 Zimmerman D, Young WF Jr, Ebersold MJ, Scheithauer BW, Kovacs K, Horvath E, Whitaker MD, Eberhardt NL, Downs TR, Frohman LA: Congenital gigantism due to growth hormone-releasing hormone excess and pituitary hyperplasia with adenomatous transformation. J Clin Endocrinol Metab 1993;76: 216-222.

35 Soya H, Suzuki M: Somatostatin rapidly restores rat growth hormone $(\mathrm{GH})$ release response attenuated by prior exposure to human GH-releasing factor in vitro. Endocrinology 1993;122:2492-2498.

36 Veldhuis JD, Roemmich JN, Rogol AD: Gender and sexual maturation-dependent contrasts in the neuroregulation of growth-hormone $(\mathrm{GH})$ secretion in prepubertal and late adolescent males and females. J Clin Endocrinol Metab 2000;85:2385-2394.

37 Hoyer D, Bell GI, Epelbaum J, Feniuk W, Humphrey PPA, O'Carrol AM, Patel YC, Schonbrunn A, Taylor JE, Reisine T: Classification and nomenclature of somatostatin receptors. Trends Pharmacol Sci 1995;16:756768.

38 Djordjijevic D, Zhang J, Priam M, Viollet C, Gourdji D, Kordon C, Epelbaum J: Effect of 17beta-estradiol on somatostatin receptor expression and inhibitory effects on growth hormone and prolactin release in rat pituitary cell cultures. Endocrinology 1998;139:2272-2277.

39 Zhang WH, Beaudet A, Tannenbaum GS: Sexually dimorphic expression of sst 1 and sst2 somatostatin receptor subtypes in the arcuate nucleus and anterior pituitary of adult rats. $\mathrm{J}$ Neuroendocrinol 1999;11:129-136.

40 Stachura ME, Tyler JM, Farmer PK: Combined effects of human growth hormone $(\mathrm{GH})$ releasing factor-44 (GRF) and somatostatin (SRIF) on post-SRIF rebound release of $\mathrm{GH}$ and prolactin: A model for GRF-SRIF modulation of secretion. Endocrinology 1988;123: 1476-1482. 
41 Buscail L, Delesque N, Esteve JP, Saint-Laurent $\mathrm{N}$, Prats $\mathrm{H}$, Clerc $\mathrm{P}$, Robberecht $\mathrm{P}$, Bell GI, Liebow C, Schally AV: Stimulation of tyrosine phosphatase and inhibition of cell proliferation by somatostatin analogues: mediation by human somatostatin receptor subtypes SSTR1 and SSTR2. Proc Natl Acad Sci USA 1994;91: 2315-2319.

42 Lanneau C, Bluet-Pajot MT, Zizzari P, Csaba Z, Dournaud P, Helboe L, Hoyer D, Pellegrini E, Tannenbaum GS, Epelbaum J, Gardette R: Involvement of the SST1 somatostatin receptor subtype in the intrahypothalamic neuronal network regulating growth hormone secretion: An in vitro and in vivo antisense study. Endocrinology 2000;141:967-979.

43 Hartman ML, Pincus SM, Johnson ML, Matthews DH, Faunt LM, Vance ML, Thorner MO, Veldhuis JD: Enhanced basal and disorderly growth hormone secretion distinguish acromegalic from normal pulsatile growth hormone release. J Clin Invest 1994;94:12771288.

44 Slama A, Videau C, Kordon C, Epelbaum J: Estradiol regulation of somatostatin receptors in the arcuate nucleus of the female rat. Neuroendocrinology 1992;56:240-245.

45 Bray MJ, Vick TM, Shah N, Anderson SM, Rice LW, Iranmanesh A, Evans WS, Veldhuis JD: Short-term estradiol replacement in postmenopausal women selectively mutes somatostatin's dose-dependent inhibition of fasting growth hormone secretion. J Clin Endocrinol Metab 2001;86:3143-3149.

46 Shintani M, Ogawa Y, Ebihara K, Aizawa-Abe M, Miyanaga F, Takaya K, Hayashi T, Inoue G, Hosoda K, Kojima M, Kangawa K, Nakao $\mathrm{K}$ : Ghrelin, an endogenous growth hormone secretagogue, is a novel orexigenic peptide that antagonizes leptin action through the activation of hypothalamic neuropeptide Y/Y1 receptor pathway. Diabetes 2001;50:227-232.

47 Kojima M, Hosoda H, Date Y, Nakazato M, Matsuo H, Kangawa K: Ghrelin is a growthhormone-releasing acylated peptide from stomach. Nature 1999;402:656-660.

48 Peino R, Baldelli R, Rodriguez-Garcia J, Rodriguez-Segade S, Kojima M, Kangawa K, Arvat $\mathrm{E}$, Ghigo E, Dieguez C, Casanueva FF: Ghrelin-induced growth hormone secretion in humans. Eur J Endocrinol 2000;143:R11R14.

49 Korbonits M, Bustin SA, Kojima M, Jordan S, Adams EF, Lowe DG, Kangawa K, Grossman $\mathrm{AB}$ : The expression of the growth hormone secretagogue receptor ligand ghrelin in norma and abnormal human pituitary and other neuroendocrine tumors. J Clin Endocrinol Metab 2001;86:881-887.

50 Tschop M, Smiley DL, Helman ML: Ghrelin induces adiposity in rodents. Nature 2000;407: 908-913.

51 Momany F, Bowers CY, Reynolds GA, Chang D, Hong A, Newland K: Conformational energy studies and in vitro and in vivo activity data on growth hormone-releasing peptides. Endocrinology 1985;114:1531-1536.
52 Arvat E, Maccario M, Di Vito L, Broglio F, Benso A, Gottero C, Papotti M, Muccioli G, Dieguez C, Casanueva FF, Deghenghi R, Camanni F, Ghigo E: Endocrine activities of ghrelin, a natural growth hormone secretagogue (GHS), in humans: comparison and interactions with hexarelin, a nonnatural peptidyl GHS, and GH-releasing hormone. J Clin Endocrinol Metab 2001;86:1169-1174.

53 Bowers CY, Reynolds GA, Durham D, Barrera CM, Pezzoli SS, Thorner MO: Growth hormone $(\mathrm{GH})$-releasing peptide stimulates $\mathrm{GH}$ release in normal men and acts synergistically with GH-releasing hormone. J Clin Endocrinol Metab 1990;70:975-982.

54 Ariyasu H, Takaya K, Tagami T, Ogawa Y, Hosoda K, Akamizu T, Suda M, Koh T, Natsui K, Toyooka S, Shirakami G, Usui T, Shimatsu A, Doi K, Hosoda H, Kojima M, Kangawa K, Nakao K: Stomach is a major source of circulating ghrelin, and feeding state determines plasma ghrelin-like immunoreactivity levels in humans. J Clin Endocrinol Metab 2001;86: 4753-4758.

55 Cummings DE, Purnell JQ, Frayo RS, Schmidova $\mathrm{K}$, Wisse BE, Weigle DS: A preprandial rise in plasma ghrelin levels suggests a role in meal initiation in humans. Diabetes 2001;50: 1714-1719.

56 Wren AM, Seal LJ, Cohen MA, Brynes AE, Frost GS, Murphy KG, Dhillo WS, Ghatei MA, Bloom SR: Ghrelin enhances appetite and increases food intake in humans. J Clin Endocrinol Metab 2001;86:5992.

57 Shuto Y, Shibasaki T, Otagiri A, Kuriyama H, Ohata H, Tamura H, Kamegai J, Sugihara H, Oikawa S, Wakabayashi I: Hypothalamic growth hormone secretagogue receptor regulates growth hormone secretion, feeding, and adiposity. J Clin Invest 2002;109:1429-1436.

58 Shah N, Evans WS, Bowers CY, Veldhuis JD: Oral estradiol administration modulates continuous intravenous growth hormone (GH)releasing peptide-2 driven $\mathrm{GH}$ secretion in postmenopausal women. J Clin Endocrinol Metab 2000;85:2649-2659.

59 Anderson SM, Shah N, Patrie JT, Evans WS, Bowers CY, Veldhuis JD: Short-term estradiol supplementation augments growth hormone $(\mathrm{GH})$-secretory responsiveness to dose-varying growth hormone-releasing peptide (GHRP-2) infusions in postmenopausal women. J Clin Endocrinol Metab 2000;86:551-560.

60 Pihoker C, Kearns GL, French D, Bowers CY: Pharmacokinetics and pharmacodynamics of growth hormone-releasing peptide-2: A phase I study in children. J Clin Endocrinol Metab 1998;83:1168-1172.

61 Bellone J, Aimaretti G, Bartolotta E, Benso L, Imbimbo BP, Lenhaerts V, Deghenghi R, Camanni F, Ghigo E: Growth hormone-releasing activity of hexarelin, a new synthetic hexapeptide, before and during puberty. J Clin Endocrinol Metab 1995;80:1090-1094.
62 Loche S, Colao A, Cappa M, Bellone J, Aimaretti G, Farello G, Faedda A, Lombardi G, Deghenghi R, Ghigo E: The growth hormone response to hexarelin in children: Reproducibility and effect of sex steroids. J Clin Endocrinol Metab 1997;82:861-864.

63 Shah N, Evans WS, Bowers CY, Veldhuis JD: Tripartite neuroendocrine activation of the human growth-hormone (GH) axis in women by continuous 24-hour GH-releasing peptide (GHRP-2) infusion: pulsatile, entropic, and nyctohemeral mechanisms. J Clin Endocrinol Metab 1999;84:2140-2150.

64 Codner E, Cassorla F, Tiulpakov AN, Merica MV, Avila A, Pescovitz OH, Svensson J, Cerchio K, Krupa D, Gertz BJ, Murphy G: Effects of oral administration of ibutamoren mesylate, a nonpeptide growth hormone secretagogue, on the growth hormone-insulin-like growth factor I axis in growth hormone-deficient children. Clin Pharmacol Ther 2001;70:91-98.

65 Klinger B, Silbergeld A, Deghenghi R, Frenkel $\mathrm{J}$, Laron Z: Desensitization from long-term intranasal treatment with hexarelin does not interfere with the biological effects of this growth hormone-releasing peptide in short children. Eur J Endocrinol 1996;134:716-719.

66 Rahim A, O'Neill PA, Shalet SM: Growth hormone status during long-term hexarelin therapy. J Clin Endocrinol Metab 1998;83:16441649.

67 Laron Z, Frenkel J, Deghenghi R, Anin S, Klinger $\mathrm{B}$, Silbergeld A: Intranasal administration of the GHRP hexarelin accelerates growth in short children. Clin Endocrinol 1995;43:631635.

68 Mericq V, Cassorla F, Salazar T, Avila A, Iniguez G, Bowers CY, Merriam GR: Effects of eight months treatment with graded doses of a growth hormone $(\mathrm{GH})$-releasing peptide in GH-deficient children. J Clin Endocrinol Metab 1998;83:2355-2360.

69 Bowers CY, Granda-Ayala R, Parulkar A, Anand M, Baker V, Reynolds GA, Veldhuis JD: Impact of GHRP-2 infusion for 30-90 days in older men and women with decreased GH secretion. Presented at the 81st Annual Endocrine Society Meeting, June 12-15, 1999, San Diego, USA.

70 Van den Berghe G, de Zegher F, Bowers CY, Wouters P, Muller P, Soetens F, Vlasselaers D, Schetz M, Verwaest C, Lauwers P, Bouillon R: Pituitary responsiveness to growth hormone (GH) releasing hormone, GH-releasing peptide- 2 and thyrotropin releasing hormone in critical illness. Clin Endocrinol 1996;45:341351.

71 Martha Jr PM, Goorman KM, Blizzard RM, Rogol AD, Veldhuis JD: Endogenous growth hormone secretion and clearance rates in normal boys as determined by deconvolution analysis: relationship to age, pubertal status and body mass. J Clin Endocrinol Metab 1992;74: 336-344.

72 Malmlof K, Bauer MK, Johansen PB, Ankersen M, Veldhuis JD: Daily low-dose GH secretagogue administration stimulates pulsatile GH secretion and elevates plasma IGF-I levels in pigs. Endocrine 2002;16:195-199. 
73 De Zegher F, Devlieger H, Eggermont E, Veldhuis JD: Properties of growth hormone and prolactin hypersecretion by the human infant on the day of birth. J Clin Endocrinol Metab 1993;76:1177-1181.

74 Wright NM, Northington FJ, Miller JD, Veldhuis JD, Rogol AD: Elevated growth hormone secretory rate in premature infants: deconvolution analysis of pulsatile $\mathrm{GH}$ secretion in the neonate. Pediatr Res 1992;32:286-290.

75 Aguila MC, McCann SM: Stimulation of somatostatin release in vitro by synthetic human growth hormone-releasing factor by a nondopaminergic mechanism. Endocrinology 1985; 117:762-765.

76 Pellegrini E, Bluet-Pajot MT, Mounier F, Bennett $\mathrm{P}$, Kordon $\mathrm{C}$, Epelbaum J: Central administration of a growth hormone $(\mathrm{GH})$ receptor mRNA antisense increases $\mathrm{GH}$ pulsatility and decreases hypothalamic somatostatin expression in rats. J Neurosci 1996;16:8140-8148.
77 Kaji H, Tai S, Okimura Y, Iguchi G, Takahashi $\mathrm{Y}$, Abe H, Chihara K: Cloning and characterization of the 5 -flanking region of the human growth hormone secretagogue receptor gene. $\mathrm{J}$ Biol Chem 1998;273:33885-33888.

78 Miki N, Ono M, Miyoshi H, Tsushima T, Shizume K: Hypothalamic growth hormone-releasing factor (GRF) participates in the negative feedback regulation of growth hormone secretion. Life Sci 1981;44:469-476.

79 Anderson SM, Wideman L, Patrie JT, Weltman A, Bowers CY, Veldhuis JD: Estradiol supplementation selectively relieves growth hormone (GH)'s autonegative feedback on GH-releasing peptide-2 (GHRP-2)-stimulated GH secretion. J Clin Endocrinol Metab 2002; 86:5904-5911.

80 Richmond E, Rogol AD, Basdemir D, Veldhuis OL, Clarke W, Bowers CY, Veldhuis JD: Accelerated escape from $\mathrm{GH}$ autonegative feedback in midpuberty in males: Evidence for timedelimited $\mathrm{GH}$-induced somatostatinergic outflow in adolescent boys. J Clin Endocrinol Metab 2002;87:3837-3844.
81 Veldhuis JD, Bidlingmaier M, Anderson SM, Wu Z, Strasburger CJ: Lowering total plasma IGF-I concentrations by way of a novel, potent and selective GH-receptor antagonist, pegvisomant (B2036-PEG), augments the amplitude of GH secretory bursts and elevates basal/nonpulsatile $\mathrm{GH}$ release in healthy women and men. $\mathrm{J}$ Clin Endocrinol Metab 2001;86:3304-3310.

82 Veldhuis JD, Bidlingmaier M, Anderson SM, Evans WS, Wu Z, Strasburger CJ: Impact of experimental blockade of peripheral growthhormone $(\mathrm{GH})$ receptors on the kinetics of endogenous and exogenous $\mathrm{GH}$ removal in healthy women and men. J Clin Endocrinol Metab 2002;87:5737-5745.

83 Veldhuis JD, Evans WS, Bowers CY: Impact of estradiol supplementation on dual peptidyl drive of growth-hormone secretion in postmenopausal women. J Clin Endocrinol Metab 2002;87:859-866. 